\title{
Lakes potency to reduce overflow discharge in the Sunter river area, Jakarta
}

\author{
T. Kadri \\ Department of Civil Engineering, Trisakti University Jakarta, Indonesia
}

\begin{abstract}
There are nine major rivers flowing through Jakarta, the capital city of Indonesia. The total extent of the nine watersheds in Jakarta and its vicinity is about 106,000 ha. The average annual rainfall of three stations (1972-2008) throughout the watersheds is $2973 \mathrm{~mm}$. The growing population and business activities have caused a tremendous conversion of land use. This problem is likely to cause an increase of surface run-off which in turn causing floods in rainy seasons.

One of the rivers which floods frequently is Sunter River. It vicinity is about $73184092 \mathrm{~m}^{2}$ and water flow $83.8 \mathrm{~m}^{3} / \mathrm{s}$ at rainfall $100 \mathrm{~mm}$. The land use in this area is very populated, so the rainfall with high intensity always causes floods. Many efforts have been made to solve the flooding but have not yet given optimum results. One effort to solve flooding is the rehabilitation of existing small lakes and building new lakes to accommodate the surface run-off. There are 5 lakes that already exist in that area (37.2 ha) and 11 alternative new small lakes to be built with 163.74 ha area.

To evaluate potency of the lakes to reduce flood risk in the Sunter river area, a hydrology simulation is done. This research showed comparative study and how effective the small lakes are in reducing flood risk.

Keywords: flood control, lake potency and model.
\end{abstract}

\section{Introduction}

Over the years lately, Jakarta has been overwhelmed by flood that causes billions of rupiah infinancial as well as material losses to the people who live along the river bank of that region. One of rivers which floods frequently is Sunter River. It vicinity is about $73,184092 \mathrm{~m}^{2}$ and water flow $83.8 \mathrm{~m}^{3} / \mathrm{s}$ at rainfall $100 \mathrm{~mm}$. The land use in this area is very populated, so the rainfall with high intensity 
always causes flooding. The flood in Sunter is getting bigger and bigger, with $100 \mathrm{~mm}$ rainfall in 2002 causing a river discharge in Sunter of $107.6 \mathrm{~m}^{3} / \mathrm{s}$. This shows a bigger discharge of water flow even though the rain was less, so that the problem of water flow in Sunter must be seriously considered.

The floods were due to the degenerating condition of the watershed of Sunter which is indicated by the river's daily maximum discharge escalation against the river's minimum water discharge. While on the other hand, the flow capacity of Sunter River $\left(35 \mathrm{~m}^{3} / \mathrm{s}\right)$ is insufficient to flow the excessive water from upstream.

Many efforts have been made to solve the flood but have not yet given optimum results. One effort to solve flooding is the rehabilitation of existing small lakes and building new lakes so as to accommodate the surface run-off and recharge ground water. There are 5 lakes that already exist in that area (37.2 ha) and 11 alternative new small lakes to be built with 163.74 ha area. The whole of Jakarta has 29 lakes and spread in this region with 10 lakes in the south, 14 lakes in the east, 3 lakes in the central area and 2 lakes in the north.

The existing lakes are meant to reduce peak discharge, and also can be used by people as a source of pure water and water source conservation mainly for recharging ground water. This research is objective to the analyzed hydrology function of lakes to reduce surface run-off that will reduce peak discharge.

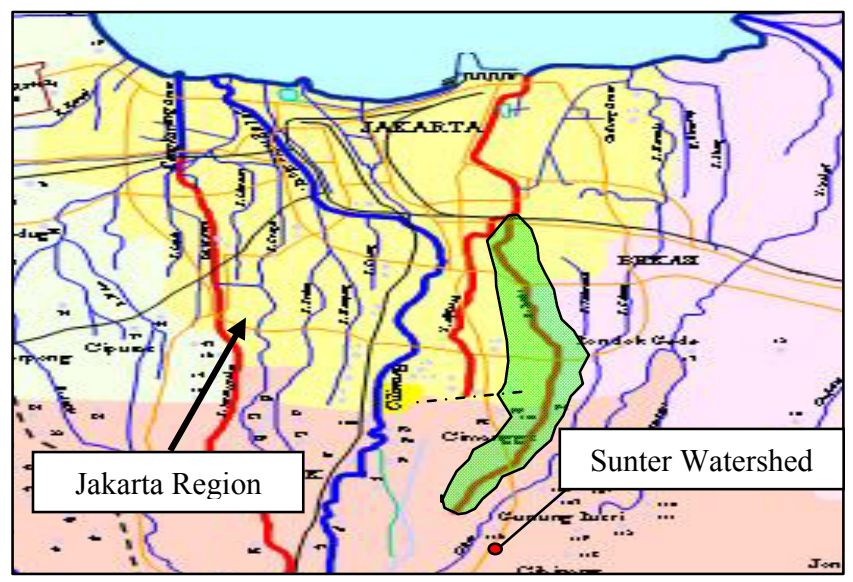

Figure 1: $\quad$ Location of the study.

\section{Hydrology characteristics and analysis}

According to the Jakarta Flood Control Master Plan 1973, the drainage system has been planned to overflow run-off discharge in area DKI Jakarta by building the West and East Flood Channel. Based on the master plan the capacity of Sunter River was $105 \mathrm{~m}^{3} / \mathrm{s}$ in 1973 , but at this time the river capacity was only $35 \mathrm{~m}^{3} / \mathrm{s}$ or only $31.8 \%$ [3].

Hydrology characteristics in the Sunter area are analyzed using rain-fall data from Halim, Cibinong, and Cileungsi Station. The rain-fall data based on data from 1973 until 2008 and achieved mean maximum daily rain is $97.5 \mathrm{~mm}$, the 
smallest maximum daily rain-fall was $66 \mathrm{~mm}$ in 1976 and the biggest maximum daily rain-fall was $162.5 \mathrm{~mm}$ in 1986 [5]. Based on hydrology analysis results of rain intensity based on return period and design discharge using Snyder method is achieved Hydrograph as in Figure 2.

The purpose of hydrology analysis on the Sunter watershed is:

a. to know hydrology characteristics,

b. to analyze the lake influence on peak discharge.

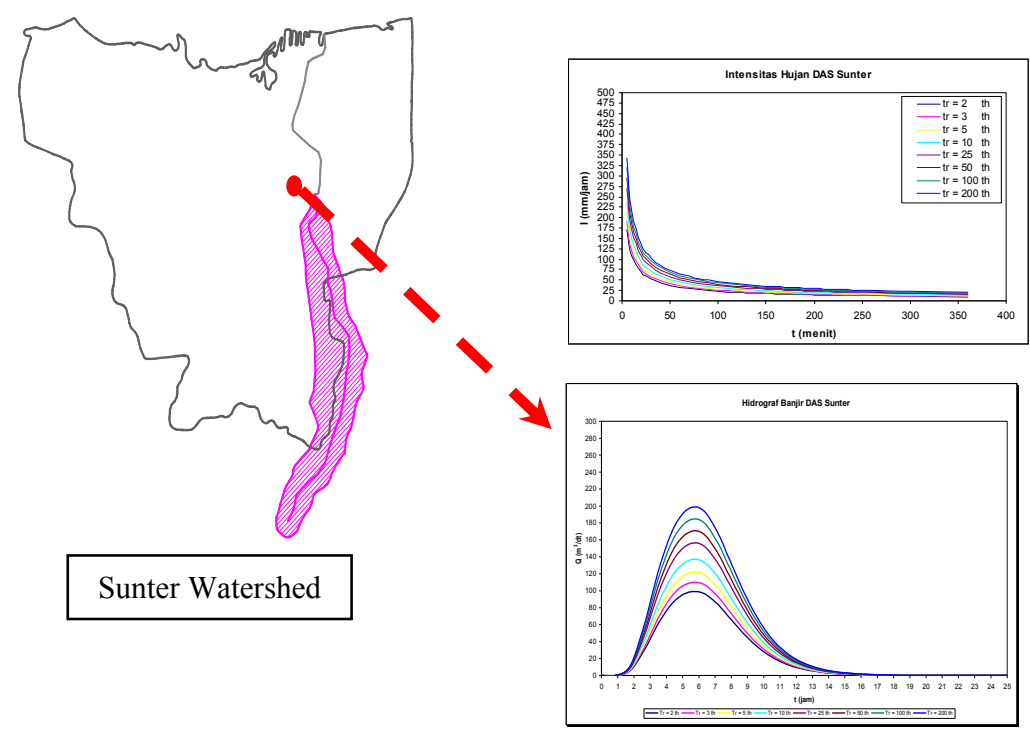

Figure 2: Intensity and hydrograph in Sunter watershed.

To know the influence of the existing lake to hydrology system of river is to use hydrology simulation. These analyses use the hydrology modelling that combine with the spatial geographical information system. The hydrology model analyzes the desain rainfall and the hydrology response of the watershed by simulation model. Hydrology modelling in this research uses HEC-HMS program Version 3.1 (Hydrologic Engineering Center-Hydrologic Modeling System).

The hydrology model system with program HEC-HMS is designed to simulate the precipitation process. This program is designed to be applied in one area to solve hydrology problems. Program HEC-HMS consists of three components that is basin, hydrometric model and specification control. The three components in HEC-HMS are supporting each other for stimulation purposes. The basin model contains a parameter that is connected with hydrology elements. 


\section{Analysis of the lake influence in peak discharge}

Sunter River with an area width of $73184092 \mathrm{~m}^{2}$ has 5 lakes most of which lie in the mainstream of the Sunter area.

Based on simulation results achieved discharge run-off while all existing lakes are rehabilitation There can be a decrease of surface run-off in the Sunter area of about $3.5 \%$ (Table 1) and if an alternative candidate has been built and achieves a decrease of $16.9 \mathrm{~m}^{3} / \mathrm{s}$ or $19.3 \%$ (Table 2 ). These results show the potency of the existing lakes to reduce surface run-off, and if it is compared to river capacity, $35 \mathrm{~m}^{3} / \mathrm{s}$ is still needed other effort to flow surface run-off.

Table 1: $\quad$ The influence of the existing lakes in the Sunter area.

\begin{tabular}{|c|c|c|c|c|c|}
\hline $\begin{array}{c}\text { Return } \\
\text { period }\end{array}$ & $\begin{array}{c}\text { Discharge } \\
\left(\mathrm{m}^{3} / \mathrm{s}\right)\end{array}$ & $\begin{array}{c}\text { Rain fall } \\
\text { design }\end{array}$ & $\begin{array}{c}\text { Run off } \\
\text { without lakes } \\
\left(\mathrm{m}^{3} / \mathrm{s}\right)\end{array}$ & $\begin{array}{c}\text { Run off } \\
\text { with lakes } \\
\left(\mathrm{m}^{3} / \mathrm{s}\right)\end{array}$ & $\begin{array}{c}\text { reduction } \\
(\%)\end{array}$ \\
\hline 25 & 154,56 & 74,37 & 87,650 & 82,660 & 3,50 \\
\hline 50 & 168,60 & 81,13 & 96,780 & 92,130 & 3,00 \\
\hline 100 & 182,55 & 90,65 & 106,320 & 101,320 & 2,49 \\
\hline
\end{tabular}

Source: Simulation.

Table 2: $\quad$ The potential influence of lakes in the Sunter area.

\begin{tabular}{|c|c|c|c|c|}
\hline $\begin{array}{c}\text { Return } \\
\text { period }\end{array}$ & $\begin{array}{c}\text { Discharge } \\
\left(\mathrm{m}^{3} / \mathrm{s}\right)\end{array}$ & $\begin{array}{c}\text { Surface Run } \\
\text { off without } \\
\text { lakes }\left(\mathrm{m}^{3} / \mathrm{s}\right)\end{array}$ & $\begin{array}{c}\text { Surface Run } \\
\text { off with lakes } \\
\left(\mathrm{m}^{3} / \mathrm{s}\right)\end{array}$ & $\begin{array}{c}\text { Surface Run } \\
\text { off with new } \\
\text { lakes }\left(\mathrm{m}^{3} / \mathrm{s}\right)\end{array}$ \\
\hline 25 & 154,56 & 87,650 & 82,660 & 70,670 \\
\hline 50 & 168,60 & 96,780 & 92,130 & 83,860 \\
\hline 100 & 182,55 & 106,320 & 101,320 & 91,830 \\
\hline
\end{tabular}

Source: Simulation.

\section{Water resources management}

It is clear from this analysis that there are frequent high floods in the rainy seasons in the Sunter area. These situations seem to be worse in the future. Therefore, the flood problem in the Sunter area needs an extremely great attention. The key to undertake these problems is a set of activities in integrated watershed management programs. The integrated watershed management program should be identical to the sustainable development program in the watersheds. Therefore, the programs should overcome the problem of frequent and high floods [4]. 
Focus of the integrated watershed management programs will be to reduce surface run-off in the whole watershed by increasing infiltration rate and to accommodate the water discharge in a safe manner without flooding. These activities should be planned carefully using appropriate models to determine what to build where and implemented accordingly.

\section{Conclusion}

The existing amount of lakes that exist in area DKI Jakarta is 29 lakes and in the Sunter area are only 5 lakes. The existing lakes in the Sunter area can give benefit to decreasing 3.5\% surface run-off in a 25 -year return period. Based on simulation results, while the lakes candidate in Sunter area will be implemented it will reduce $19.3 \%$ of peak discharge in a 25 -year return period. These results show the potency of the existing lakes to reduce surface run-off, and if it is compared to river capacity, $35 \mathrm{~m}^{3} / \mathrm{s}$ other effort is still needed to flow surface run-off. Flood problems in the Sunter area need an extremely great attention. The key to undertake the problems is a set of activities in integrated watershed management programs.

\section{References}

[1] Fongers D., A Hydrologic Study of the Ryerson Creek Watershed Hydrologic Studies Unit, Land and Water Management, Division Michigan Department of Environmental Quality, Michigan, 2002.

[2] Johnson C., Yung A., Nixon K. \& Legates D., The use of HEC-GeoHMS and HEC-HMS to Perform Grid-Based Hydrology Analysis of a Watershed, Dodson \& Associated, inc., Texas, 2002.

[3] Nedeco, Master Plan for Drainage and Flood Control of Jakarta, Jakarta, 1973.

[4] Pistocchi A. \& Mazzoli P., Use of HEC-RAS and HEC-HMS model with ArcView for Hydrologic Risk Management, Fortly-Italy, 2001.

[5] Sinukaban, N. \& Kadri, T., Integrated Watershed Management to Prevent Floods and Sustain Water Resources In Jakarta, Indonesia, Balwois, 1987.

[6] WJEMP, Outline Plan for Major Drainage and Small Lakes in JabodetabekBopunjur Area, Government of DKI Jakarta. 2005. 